\title{
How the Immigrant has Become Muslim
}

Public Debates on Islam in Europe

Stefano Allievi

\section{(2) OpenEdition}

Journals

Electronic version

URL: https://journals.openedition.org/remi/2497

DOI: $10.4000 /$ remi.2497

ISSN: $1777-5418$

Publisher

Université de Poitiers

\section{Printed version}

Date of publication: 1 June 2005

Number of pages: 135-163

ISBN: 2-911627-40-7

ISSN: 0765-0752

Electronic reference

Stefano Allievi, "How the Immigrant has Become Muslim", Revue européenne des migrations

internationales [Online], vol. $21-n^{\circ} 2$ | 2005, Online since 01 October 2008, connection on 14 April 2022.

URL: http://journals.openedition.org/remi/2497 ; DOI: https://doi.org/10.4000/remi.2497

This text was automatically generated on 14 April 2022.

(c) Université de Poitiers 


\title{
How the Immigrant has Become Muslim
}

\author{
Public Debates on Islam in Europe
}

Stefano Allievi

« Fondement - Toutes les nouvelles en

manquent»

Gustave Flaubert, Dictionnaire des idées reçues

\section{Premise: conceptualising otherness}

1 The 20th century could be defined from the point of view of Western thought the "age of the other" ${ }^{1}$.

2 The entire history of contemporary philosophy, from phenomenology to existentialism, right up to Ricœur and Lévinas, is actually a reflection and a continual reconceptualisation of and about the "other", and the identity-otherness polarity. Psychology, from Freud onwards, has made us familiar with the idea of the "other as a mirror of oneself", making us sees the other's gaze as a constituent element of our own identity: without which we do not exist, or find it difficult to define ourselves.

3 All modern anthropology, as opposed to "missionary" ethnology (included the one that supported and collaborated with the imperial conquest and colonisation, following the idea of "the white man's "burde", a secular mission, so to speak), is based precisely on the recognition of the other as such, on the acceptance of the other's identity and on making legitimate the other's diversity, leading us to search for it and also to safeguard it: recognising that the loss of cultural diversity, far from being a victory of "progress", is in itself negative (a recognition without which there would be no anthropology, nor would it be possible in any proper sense, as we have learned through Lévi-Strauss and many others).

4 These idea of the "other" can be summed up in the synthesis, unfortunately difficult to translate properly, that Edmond Jabés made in a precious book (Jabés, 1989): "L'étranger? L'étrange-je". Something similar is implicitly formulated in the expression 
alter ego: without alter, ego does not exist; and at the same time alter has in common, with me and with everyone, the fact of being ego.

Sociology has gone through a significant curve of development. Tempted from its beginnings and right up to the great functionalist syntheses, above all by "social modellism", which had an effect of uniformity and was in a certain sense conceptually authoritarian (from Comte and Durkheim to Parsons), it found itself having to measure up with the figure of the "other": above all the deviant, precisely he who deviates from the norm and normality, the outsider. Following on which it set about, with the great classics (in particular Simmel, Sombart, Schütz, and then with Park - who had followed Simmel's courses and influenced the Chicago school with his personality - Elias and others), and up to many classics today's sociologists, to observe the figures who actually threw the idea of uniformity and homogeneity into greatest crisis, and so implicitly the idea of system, in itself unitary, uniforming and stable. These "figures of otherness", which have had a certain importance, and have been properly conceptualised, have been above all "internal" foreigners (belonging to a minority: historically Jews, and then members of ethnic and religious minorities, and successively also defined culturally or differently: think today of certain interpretations of sexual minorities, for example), the "cosmopolitan type", and lastly immigrants.

6 We could stop here: the ideal type of the other, the most recent, the most studied, for a long period has in fact been that special type of foreigner that is the immigrant. Seen usually as a worker and often, in the Anglo-Saxon sociology (much less in the Continental one) through the lens of race relations.

7 For many years the analysis (quite rightly contested) passed through various kinds of reductionism: the immigrant seen only as homo ceconomicus, so as labour force, and with his economic consequences (on the GNP or unemployment rates, the Welfare state, etc.) - remember the synthetic criticism of this view of the immigrant implicit in the Swiss writer Max Frisch's statement: "We were expecting arms [for work] ${ }^{2}$, we received men". Successively research broadened out to include what is attached to the arm, so to speak: the arrival of men, with all the complexity of their needs, their expectancies, their social and religious practices, their appurtenances. And then, much later, the discovery of the gender dimension of immigration: not only men, but women, families, and with them children, the "discovery" of the second generations, and their problematic specificities. Following on this, the dimensions of mixité: conjugal, but also more generically cultural, with which the concepts of hybridisation made their way into the field of study (with authors such as Gruzinski, Amselle, Bhabha), métissage, creolization, all in all a different and opposing analytical point of view, more attentive to the dynamics of change than to those of cultural continuity. A point of view, it is worth noting immediately, that is singularly little used when Islam is spoken of: as if it was more difficult or impossible for it, as if it were incapable of mixing and creolization. We already observe here the essentialism that a great deal of research attributes by default to Islam, but much less to other cultures and religions. 


\section{Why are religious categories so salient today in the study of migrations?}

8 The other, the different, the foreigner, the immigrant. And today the Muslim. A path that has unravelled in the course of the decades and which in particular has transformed one category into the other, through a semantic shift and a selective perception of not little importance, which corresponds only in part to real changes.

9 If in fact right from the years of the post-War reconstruction and the economic boom it was the category of the immigrant that prevailed, from the 70s, and in a more decisive manner afterwards (with many differences according to the country, and the respective migratory situation) the Muslim became increasingly visible, for many reasons.

10 In central-northern Europe the turning point came in the 70s when, following on the oil crisis and the consequent economic crisis, immigrants began to realise that they would have to consider their presence in Europe as no longer transitory, but definitive. Or, more brutally, they found themselves faced by the alternative of returning home, which would make it impossible for them to re-enter Europe (also in the wake of the progressive approval practically everywhere of more restrictive immigration laws, which would make the coming and going that in many cases had previously been the norm impossible), and a definitive acceptance of their European horizon, with the consequent need to put down roots, also culturally - also following the presence of those who are wrongly called second generations, but which, not having ever moved, are actually the first generation of autochthones.

11 We can quite rightly say that the immigrants coming from Muslim countries brought Islam with them, in their suitcases. But for many years they left it there: not only were they not perceived as Muslims (the Turks in Germany were just Turks, the IndoPakistanis in Great Britain only immigrants from the ex-colonies, as were Algerians in France - and everywhere in Europe classification, perception and also study were limited to ethnic and national variables), but they themselves considered themselves essentially immigrants, transitory to boot (the weight of the "myth of

the return" in all this, typical of the first generations of immigrants, should be considered) ${ }^{3}$. Their Islam, the weight of the religious variable, all the more so if lived collectively and in a community, was, all things considered, secondary: Islam, if it was there, often remained in the suitcase, or at most was relegated to the private sphere, with few exceptions ${ }^{4}$.

In Southern European countries the situation was different. Italy, Spain and others became countries of immigration only in the 70 s after having had for centuries countries of emigration. For them the change was even stronger and more rapid. They too passed through the stage of sole ethnicisation of immigration (perceived on the basis of the countries or areas of provenance). But the stage of Islamisation of immigration, to use a deliberately strong expression, came first, and already with the first generations, without any need for a second generation towards which they would feel the need to transmit their cultural and religious capital. 
There were many reasons for this:

- the diversification of countries of provenance, which actually prevented identification, both at the institutional level and that of perception, with a single country and, on the contrary, favour the identification with religious rather than ethnic references;

- the greater speed of entry and settlement, and the more recent arrival, in a situation in which also in the countries of origin Islam had in the meantime become central in the construction of the public space, on the religious, political and cultural plane, (much more than in the 70s and early 80s, for example, when most immigration took place in central and northern Europe);

- the scarcity of arrivals from ex-colonies with pre-existing ties (for example of culture and language), and a tradition of mutual knowledge;

- the important role played by the converts in the "social production of Islam" (in the associative world), cultural (media visibility, reviews, websites, publishing, translations), and political, with a more general role of assistance in the organisational problems of the Muslim immigrants, and with a clear interest in making interpretative categories of the religious kind prevail;

- the greater dispersion in work and housing, which does not favour the phenomenon of the "ethnic threshold", and a lack or relative weakness, at least for now, of associative secular interlocutors (ethnic and cultural) of any representative weight, which make the social and religious role played by the mosque network even more relevant. Mosques, in short, and everything that revolves around them, seem to play in these countries a more important role, if only because highlighted by the inadequacy or weakness of other interlocutors, than they do in other European countries.

So it seems strange if seen with the eyes of the present cultural debate, but there was a time, not so far off, when Muslims in Europe were only immigrants. Why has the situation changed?

There are internal reasons connected with the world of migrations we have already seen. Then there are reasons connected with the emergence of Islam as a disruptive element, also on the symbolic plane: as a global geo-political actor (from the local crises connected with Islam - Afghanistan, Algeria, Bosnia, the always significant but ever more Islamically interpreted Palestine, Chechnya and many others - up to transnational Islamic terrorism and the impact of the terrorist attack upon the Twin Towers, and then, still in the West, the attacks upon Madrid and elsewhere); as an instrument and interpretative category (from Huntington onwards, in a very widespread literature, above all in its more popular versions); as a social and political actor of ever greater importance also in the countries of origin of the European immigrants.

But there are also long-term reasons (the deep currents, to use an expression dear to Braudel, more important even if less observed than the histoire évènementielle, which does not represent anything but the froth on the surface waves), internal to the European West, which do not have to do only with Islam, but more in general with tendencies of religions as a whole.

The last thirty years, in particular, have led to a radical transformation in the religious field in various European countries: which have become (all, even those traditionally religiously monopolists like Catholic Italy and Spain), on the religious level, more and more plural. This process has taken place for two reasons: a process of pluralisation inside the dominant religious field (whether Catholic or Protestant, and in various 
grades in-between), and a progressively greater presence of other religions, or of other ways of being religious, as well as non-religious options, or of abandonment of the religious field altogether.

This second element of pluralisation was in its turn due to two tendencies: an internal pluralisation, autochthonous, produced in the resident population; and the arrival of allochthonous populations, with religions different from those already present in the country (and at times different ways of belonging to the same religions).

If the fact of progressive religious pluralisation was considered both as a fact and a tendency in progress, it was not perceived as being such to the same degree: the public, media and political discourse on religion remained still essentially very close to the dominant religious institutions as majority religions (or too hastily identified as such).

This change in the religious field took place in a period that, in contrast to other periods in the recent history of Europe, was seeing religion ever more present in public discourse (Casanova, 1994), for reasons connected as much with processes of globalisation and their cultural consequences (Kurtz, 1995), as the effect of media visibility that only had in part the same origins.

In speaking about Islam, why am I referring to a more general and undifferentiated pluralisation of the religious field? Because I have the very strong feeling that in public discussion Islam has taken on a crucial role among other religions, because in a certain sense it represents the extreme case (or to be precise, the case perceived as such) of pluralisation itself: discussion of and on Islam, with the historical and symbolic overload it carries with it, reassumes and in a certain sense replaces discussion about pluralisation, which has taken place and is on the increase, but is not at all understood and even less digested, metabolised, by the social body.

This is a problem that is strongly present specifically in the social sciences, which still need to really come to terms with religious pluralisation and its persistent and perhaps increased salience in social experience. And, above all, they do not yet dispose of an adequate conceptual and methodological range of instruments to grasp and understand it ${ }^{5}$.

\section{Religious specificity as object of study: a sociological problem or a problem for sociology?}

One of the elements of otherness that foreigner bring with him is naturally the religious element. And I say naturally because in some cases we are dealing with foreigners coming from cultures (you come from a cultural universe in a more radical and significant manner than you come from a country, even if we find this latter expression, wrongly, more congenial) in which religious identity is central and crucial for defining the cultural and also personal identity of the individual, as well as certain important social subjects.

This in itself, far from being an explanation, is for Western social scientists a problem: because they do not necessarily find themselves in the same situation. Actually, they nearly always find themselves in a situation that is very different: and this may even cause them problems of understanding and being at one with the situation. 
And when the religious universe in question is Islam, the difficulty of comprehension can become much greater and change into a serious interpretative handicap (even if the fact that it is serious does not necessarily mean that it is taken seriously) and this for various reasons.

The first is that Islam itself is a world that is very little known, a bit all over the West, which is the heir of a long historical period in the course of which Islam was not only another world, different, unknown, but actually the enemy; and when you have to describe the enemy you do not usually worry about treading too heavily, nor do you worry about being objective. This legacy is more alive now than ever before; more in any case than we would tend to believe. And it is also visible in the attitude, at least implicit, of not a few works on the subject: also in the scientific and academic field (to take one example, think of Huntington, 1996, and the conspicuous line of inquiry, or rather interpretation, that he has produced). But this is a trend that is getting stronger and stronger, with best-selling books and not only, above all since with the fall of the Berlin wall the West lost its traditional enemy to the East; and, in the thinking and practice of some, it is replacing it with a new enemy, to the South (who because of intrinsic features, but above all because of the complicated play of mutual perception, lends himself very well to this role). September 11 did the rest, by making Islamic terrorism break in and explodes - literally - on the public scene, inevitably giving the " coup de grâce » to any non-emotional or politically correct reading of Islam.

The second reason regards sociology specifically. When this has been applied to the religious phenomenon of Christianity it has nearly always stooped to analysing its role, however intended (see Weber in the Protestant Ethics and the Spirit of Capitalism, one of the works that have left a mark on sociology, and not only religious). Or perhaps, already with Durkheim, aware that "religion is the first of all social phenomena", it went to seek in religious phenomena at a primary stage the "elementary forms" of what at a more elaborated stage was to be found also in contemporary society. Other religions, like Hebraism, have possibly for different reasons been given greater attention (think of Sombart, among others). Islam has instead remained among the great unknowns of sociology.

First of all because (as opposed to Hebraism) it was not present in Europe, not even as a minority (and it was a minority, after all, from which Christianity derived, so there was a reason for interest in it, too).

Secondly because Islam as a subject of study has been up to most recent times the prerogative of Classical Oriental studies, and so also a prisoner of its methods of study and its interests, only rarely enriched by any sociological sensibility.

Last but not least, because there is no possible reference to an attested tradition. Islam is only now starting to enter sociology books, and badly, often in a banal way: perhaps just for the sake of making a necessary reference to a phenomenon that cannot be avoided, but often for less noble reasons - simply to sell.

\section{Sociology and Islam: notes for a history}

The study of Islam by sociology is a complex problem. Complex, and in no way defined, not even in its broad outlines. Sociological study of Islam is in fact relatively "young", much younger than a discipline which is itself young, with little more than a century of 
life, even if the offspring and heir of other contributions. And it is like this despite the fact that the study of religious phenomena, which has now become a specialised sociology and, at least in Europe, secondary (the sociology of religions, for the record), was instead, at the beginnings of the discipline, the centre itself and the main object of its reflections: think of Durkheim, but also, in a different manner, Comte, not to mention Weber, who dedicated most of his intellectual energies to it, to the point of attempting a gigantic comparative work, in his Sociology of Religions, left unfinished.

This was however a sociology that was essentially centred on the phenomenon of Christianity, as we have seen: it took this as its starting point and proceeded in continual confrontation with it, often polemically and to a certain extent "in competition" with it. A confrontation that went on beyond any "universalising" ambitions, those daughters of the age in which sociology was born and of its Illuministic presumption, evident as much in Comte's law of the three stages as in Durkheim's Elementary forms of religious life - both convinced that they had found general laws, applicable everywhere, of universal value.

Islam however was not able to enjoy so much attention: much less, I would say, than the "primitive" religions, as well as the Aboriginal ones that served as a basis for Durkheim. And the pre-comprehensions about Islam and the polemical legacy of theological interpretation undoubtedly weighed heavily, as did the authority but also the peculiar distortions of the Orientalist legacy, too. At the same time sociology was less implicated than its cousin disciplines - I am thinking of anthropology - in the fieldwork (including its notorious colonial "complicity"). There were many reasons for this, of which one would seem to be decisive even if completely absent from the debate on the subject: the fact that sociology was born as an inquiry into the effects of modernity (whatever we may mean by this term), and the changes induced by it in developed societies: so it was born as a Western and modern science. And Islam, like other cultural worlds, was, or rather was and is still often perceived as, whether rightly or wrongly, non-Western (when not anti-Western) and non-modern (when not antimodern). Here is the explanation for the delay of sociology - to blame certainly, but inside this framework it is understandable - in dealing in general with other cultural worlds rather than Western ones (not only of Islam, but also of Islam); as well as, in other ways, the failed or weak development of sociology in Muslim countries, despite the call, often purely rhetorical, to the legacy of Ibn Khaldun.

Here are, in synthesis, some of the reasons that make sociological study of Islam a discipline (I deliberately avoid the term "science", even if it is used, with too much presumption and lightness, in other disciplines too), still young. Which makes it difficult to speak of different schools, for example. At this stage we are still at the beginning: at the building of the foundations.

Perhaps, to use a synthetic expression (which, however could be, as Karl Kraus said of aphorisms, "either half-truth, or a truth and a half"), it is Weber's fault, and the lack of attention on the part of sociologists to Islam goes back to the fact that Weber did not manage to introduce it in time in a systematic manner into his vast comparative edifice, a necessary point of reference for any social scientist wanting to study religions. Others did it after him (Turner, 1974; Carrè, 1986), but without his authority, and actually with not many results and very few intuitions, in addition nearly all close to the "political", macro, dimension. 
In fact even today sociology texts on Islam can be counted on the fingers of one hand, or not much more (Charnay, 1977), and those that are entitled to this position often speak of something completely different and are not sociological works at all (Shari'ati, 1979). Only recently have we seen some rare attempt to make Islam the object of study in itself (Dassetto, 1996; Pace, 1999). And unfortunately an autochthonous sociology of Islam, born from within the Islamic countries themselves, has been late in appearing, for reasons that would be too long to go into here (Sabagh and Ghazalla, 1986; Maatouk, 1992; Abaza, 1993). It took time for it to be born and developed, and although able to count on noble and ancient forbears (the already cited Ibn Khaldun, perhaps considered with some exaggeration a sort of forerunner of social studies, and not only in the Islamic world), with the exception of important but not sufficient exceptions, it suffers from difficulties in its context (including - not a small problem - repression and lack of democracy, that clearly do not help freedom of research) and a lack of means at its disposal. Even if it is more lively and interesting than is generally known or admitted in the West.

The overall result is that a great number of studies of Islam, and consequently also Islam in Europe, are also in their theoretical foundations if not necessarily in methodology, differently derived from sociological ones. Furthermore, in some hot subjects, there is an excessive number of studies with a political bias, with all the consequences and all the "vices" and deformations that arise in these cases: among which the overexposure to political Islam, and excessive attention to fundamentalist movements. May be comprehensible, in the wake of present geopolitical events; but less ethically "neutral" than we might legitimately believe, when applied perhaps too lightly to a reading of social processes inside Europe. With important consequences in the formation of the social public imagination.

\section{How and when the immigrant became a Muslim}

39 In the last thirty years, as we have seen, a new element of reflection, and a new analytical point of view, has burst on to the scene: privileging reflection of a cultural nature, specifically religious. At the risk of producing a new reductionism: immigrants always seen more as Muslims, less as workers, students, parents, children, etc., starting, that is, from their (pre-supposed) identities, rather than the roles they have. A way to re-introduce the category not only of diversity, but also otherness, if not extraneousness, and even, as a consequence that is sometimes theorised, incompatibility, in situations in which it was no longer verifiable and demonstrable from other points of view (think in particular of the second generations: no longer immigrants, less and less "other", always less different - but who, when "Islamised", re-become "other" and different and even extraneous, according to the interpretations).

This is a debate that was born outside academia and social research: in debates that are invading the public space, in politics, in the media, in certain religious considerations, in many popular essays. But which are also entering sociology strongly. First of all, as a response to a lack, an underestimation, that might be considered indecent and most unscientific, of the cultural and religious element, obvious both in only social interpretations and in the race relations approach, which aimed at a specific interpretation of racism and tended to underestimate other aspects. Then as a path of 
research: it is the case of much research on European Islam that at a certain point not only the sociological debate began to enter but also that of the wider public, a sign of an already mature interest. Lastly, as an element of social debate and in more deleterious cases of a new, more subtle and more potent form of xenophobia.

The literature that sees the Muslim as different, the "other", at times the enemy (mostly extra-sociological, it must be said, even if there are exceptions), is spreading, together with the research that just makes Islam its subject of research and its fieldwork. Lately however, at least at the level of the wider public, the first seems to be getting the better of the second.

One of the paradoxes of this situation is that today, when we find ourselves in a notsimple moment of transition between an Islam in Europe and an Islam of Europe (with signs already of the construction of a European Islam), it seems that the situation of the Islamic presence could be synthesized with this slogan: substantial integration, conflictual perception.

We have no space here to even mention the figures, not only demographical and economic, for the Islamic presence in Europe, which I will just take for granted (see however Maréchal, Allievi, Dassetto and Nielsen, 2003).

I would just say that substantial integration - no different for Muslims in its positive and negative aspects from for other immigrants - is what we see in the workplace, in school, in many districts. Perception of conflict is what the cultural (or sub-cultural, because it often would be too much to call it that) debate reveals, in one part of the media, in the political world, but also in parts of the cultural and religious establishment.

On the one hand we have the normality of immigration, on the other the exceptional nature of how it is perceived (which is not found in similar forms and modes with other immigrations, even if they are not less "other" that the Islamic one in respect to European history).

It is obvious that the exceptionality of the interpretation has many good reasons on its side, which come to us mainly from the present geo-political situation and the growth of trans-national Islamic terrorism's capacity to strike (the West and its public imagination). But it is equally true that this does not explain everything. The conflictual interpretation of the Islamic presence in Europe, and the spread of a popular Huntingtonian interpretation of the "clash of civilizations", in fact precedes September 11, 2001, and we find it in the press, in the popularity of the word jihad, in conflicts over the hijab or in urban conflicts concerning mosques and cemeteries, as well as in political parties and religious movements and movements of opinion which had chosen Islam as a target well before "black September" (see my chapters on The Media and Relations and Negotiations in Maréchal, Allievi, Dassetto and Nielsen, 2003).

So the problem precedes geo-politics and terrorism, and has profound roots and a symbolic overload that must be held in consideration. Only this can explain the fierceness of certain attitudes to Islam circulating in the European public space, in which sometimes it would suffice to substitute the word "Jew" for the word "Muslim" to understand their gravity and negative potentiality.

48 Naturally, in this process of demonising Islam, a more general process of social construction of fear plays a crucial role, which is part of that more general transformation of our society into a "risk society" (Beck, 1992). A fear whose general 
meaning is now a "long-term tendency" of the contemporary West, from which many draw advantage, and whose specific anti-Islamic aspect is also creating advances in political and intellectual positions, and extremely concrete economic profits (think of the media, or anti-Islamic libels: what people forget to say is that this is a literary genre that is selling very well, much better than any dialogue about civilisation or religion).

\section{European Islam}

The case of "European Islam" deserves special attention because of one simple but decisive fact: in the space of one generation, in just a few years in some countries, it has become the second religious presence in Europe, after the Christian presence seen globally: a presence that can be considered definitive and irreversible. A turning point that is not emphatic to call historic.

And it is not an entity in transition, only temporarily present, perhaps against its will as some would like - returnable to the sender: like the foreigner in Simmel (1908), he is not the one "who comes today and goes tomorrow, but (like) him who comes today and tomorrow remains". It is the distant subject that has become near, to remain inside the Simmelian terminology.

51 To Muslims by origin we have to add a not-overwhelming number, but becoming increasingly significant, of European converts, whose role and function in some countries, is becoming more important than the statistical evidence would seem to show (see Allievi, 1998; Social Compass, 1999; van Nieuwkerk, forthcoming). Furthermore a second and third generation of Muslims can call themselves European to all effects, and represent - together with the converts, but with greater numbers and more complex qualitative implications - the first real autochthonous European Islam (often -particularly in France, UK, and in other countries with lower percentages - also "citizen" to all effects, and so endowed with full rights, including political ones, see Khosrokhavar, 1997; Vertovec e Rogers, 1998). An Islam that is changing, evolving, which for many reasons is no longer the Islam of the fathers, without for this in any way losing its identity by being dispersed in the sea of the indeterminate and undifferentiated.

52 An Islam in evolution, then, but which in this very process sanction its progressive stabilisation, and offers its candidacy to become part of the cultural

identity of the new Europe in the process of a difficult construction. An Islam furthermore that is minoritarian, which in this condition and with little hope of changing has to play its role and negotiate its space in society, on a par with other religious and cultural minorities: not a small change, also "theological", all still to work out, but which promises interesting results and a feedback effect in the future with Islamic countries of origin- implications that European Islam is only now beginning, and with difficulty, to be aware of (or perhaps it is not even beginning: it may be simply riding them out). Islam is changing, but Europe is changing too: "reality in change, but also of change" (Dassetto, 1996).

But how is it being studied, this changing Islam?

The sociological analysis of Islam in Europe often tends to compare the situation in the different countries of Europe by comparing different national cases (France, Great Britain, Germany, sometimes Holland and Belgium and less frequently the 
Mediterranean countries of Southern Europe and the Scandinavian countries). Often these works are not really of comparison, because they are not the product of the work of a single researcher or team of researchers: they simply put together papers or essays by various authors, rarely with a common structure and objectives ${ }^{6}$.

Another frequent approach is to study the presence of Muslim populations in a particular local environment, or in a specific country ${ }^{7}$.

A third kind of research includes the study of a specific ethnic or national group (for instance the Senegalese in Italy or the Turks in Germany), in some cases with part of the research conducted in the countries of origin ${ }^{8}$.

Only rarely has a synthesis of the different processes at work been attempted, on a more general level, by specialists who have attempted to describe different implications of the presence of Islam in Europe ${ }^{9}$. In very rare cases, the synthesis has been the outcome of a research project (Maréchal, Allievi, Dassetto and Nielsen, 2003).

\section{Approaches to Islam: the risks of research, between reductionism and essentialism}

58 The risks that research on Islam in migration runs are, I believe, essentially twofold: one is being misunderstood and the other, the contrary and a mirror image of the preceding one, is an excess of prominence.

Being misunderstood is obviously all about not considering its being above all a religious fact, even if social too (social and religious, and perhaps, according to the teaching of some of the classics, social because religious); it leads to the common temptation to consider it one cultural element among the many, explainable, today that reductionisms of an economic and historicist kind are no longer in fashion, in terms of the sociology of migrations; a factor that can also be manipulated by host societies as by many others, in tension like all of them (the immigrant as a subject between two cultures, etc.) and like many others easily re-absorbable by the stronger culture.

60 The excess of prominence consists instead in the highlighting of only one - supposed peculiarity, defined a priori (usually in ways that also owe much to an unconsciously Orientalistic approach), with which is explained, or there is an attempt to explain, every possible act and form of behaviour of Muslims - also what could be attributed to other factors.

61 Often the first approach only sees the individual dimension of Islam, and can predict its absorption (this at least was what it was like initially and emphasised more in French sociology, or sociology influenced by it). The second approach instead tends to accentuate the communitarian dimension of Islam, and often fears (or at times exalts) its irreducible diversity.

If in the intellectual prejudice that "forgets" the religious aspect the risk (and for some, "pre-judicially" we might say, the aim) is the failed recognition of a specificity, the desire to read it at all costs in another key - a form of reductionism - the incomprehension of the reality can also manifest itself in the opposite way.

63 A good example may be a certain kind of Orientalism (or worse, its mass media version) incapable of distinguishing between the Islam described in books and that lived (or 
even not lived) by Muslims, who recognise themselves more or less (or do not recognise themselves) in it: a form of essentialism, which basically proceeds from a predefined image of what Islam is, in which it tries to bodily collocate in flesh and blood those Muslims that find themselves in its path. And if they do not fit, too bad for them... An approach that is not limited to Orientalism. Many of these (theologians, political experts, journalists and sociologists) who, in second-hand works, borrow concepts about the Islam of Muslim countries (majoritarian Islam) and apply them slavishly to the Islam of Europe (minoritarian), and do not grasp their fundamental diversity, are carrying out precisely this sort of essentialist operation ${ }^{10}$.

Essentialism, the search for "what a thing cannot but be", which in other fields led to fertile developments, runs the risk of being quite misleading in sociology (specifically in the sociology of Islam), even if it responds to some characteristics that make it attractive as a method from the point of view of the scholar: it is relatively easy to study, it has an undoubted didactic efficacy, it gives the illusion of immediate comprehension and thus satisfies any anxieties as to interpretation, and it adapts very well to academic rituals (cultured citations, footnotes, attachment to a tradition, ritual homage to past masters, etc.). It also has debatable results in the kind of "reflexivity" it produces on society, leading to a pre-interpretation in cultural and religious terms that is both scientifically and politically problematic in its consequences (Martiniello, 1997).

A way of proceeding, this, that makes it difficult to distinguish - an operation which is heuristically indispensable - between three levels of reading that are conceptually distinct, but which often overlap in the analysis: Islam "in itself", so to speak (theology, legal studies); Islam as a model (social, political, cultural, religious) that exists concretely, but which has many and diverse applications and articulations in the Muslim world; and lastly Islam in Europe, which finds itself in a completely different situation from that of its countries of origin (but what origin, from the second generations on, born in the European context?), as different from that described by Islam as a principle of reference, the one that I have called for want of a better term Islam "in itself".

These are the reasons for which scholars and researchers, who at a certain point had begun to deal a little more closely with the phenomenon of immigration, have not so far fully understood (with important exceptions) the weight of this religious specificity. They too, they above all, have been the victims of a peculiar form of cross-eyed vision.

In part because of pre-judicial questions, to be understood as we have seen in a literal sense: the emergence of the religious factor as the characterising factor of a social phenomenon is something that is intellectually extraneous and ideologically troublesome for a consistent opinion, also, and perhaps above all, in the intellectual milieu ("the speaking class", as it has been called), which has often revealed itself to be, especially in the past, not well equipped to understand it as such, and in some cases not very willing even to want to recognise it. On the other hand a-critical emphasis on the religious factor itself, the tendency to explain everything as stemming from it, underestimating or completely forgetting the social, cultural and political dimension, is in a certain sense the other side of the preceding error, and shows the same incomprehension. Which means that - to give an example of the mechanism at work if an Egyptian beats his wife who is, say, Spanish, the initial interpretative factor is religious, and there we go to look for explanations of the behaviour; level of education, social class, rural or urban provenance, but also just the pure and simple psychological 
variability of individuals, tend to get lost (for example, much reflection on so-called mixed couples suffers from this over-representation of the role of religion: on both religious sides, in the media, etc.).

Those who want to study "sociological Islam" should move between reductionism and essentialism, in a delicate balance which is not easy to keep, above all if they intend to start from the concrete behaviour of Muslims: so dealing with lived Islam, using the Islam described in the pages of newspapers and books only as an indispensable instrument of analysis, and knowable and recognisable through these. In any case, between reductionism and essentialism, and before these, there must be the observation of the phenomenon (and a phenomenon, it must be said in brackets, that leaves very few written traces: so that either you observe it directly, in its empirical manifestations, or it simply escapes us).

The problem is that direct observation is tiring and costly, and uses up much time and money. It is not strange, therefore, that today many people, not only journalists, are choosing easier interpretative shortcuts: telling us for example what is happening in European mosques without feeling any need to set foot inside them. What is surprising is nobody finds this surprising; that it is accepted both in its deontology and in its conclusions. The interpretation of a phenomenon cannot logically precede observation and description. The fact that there are many people who are prepared to theorise before having analysed and described is not only an intellectual perversion that goes well beyond the subject in question, but is a sign that the subject is hot, sensitive (from many points of view: political, cultural, religious, of customs, even sexual) and a symptom of that frequent and peculiar over-exposition to media to which Islam is subject. All the more reason for insisting on proceeding more carefully.

So there is a need for much more inquiry, both qualitative and quantitative. The quantitative is still too scarce, above all in respect to the excess of "explanations" offered on the subject, which suffer from having a definitely inadequate empirical base. But more than large surveys, it is the specific and qualitative inquiries, of ethnic communities, associations, or the most diverse groups, that can be more precious at this stage. Perhaps because despite the passing of the years we find ourselves in a phase that is relatively approximate in development, it would be better not to let the second precede or prevail, that is, the quantitative research over the qualitative. The contexts of the various countries are in fact different, as are also the migratory components and the times and modes of the migratory and economic cycles; so that also from the conceptual point of view there is need for theoretical refinement and contextualisation of conceptualisation itself. In short, as always, both are necessary, qualitative and quantitative research (after all they respond to different research aims). Remembering however that the first may be empty without the second, but the second without the first is blind. In short, we need the scientific humility of being able to start from the beginning again: also in "qualifying" and conceptualising.

71 All in all it would seem to be useful for everyone to attempt to shift from systemic comparisons to an empirical analysis of the data offered us by the reality of the Islamic presence in Europe, and also by the changes in progress in the countries of origin: from Islam to Muslims, or if we prefer, from systems to social actors. To then return, supported by a more solid basis for verification, as is right and necessary, to the systems. 


\section{Reactive identities}

72 In this phase, in which the interpretative paradigms (also those of common discourses, not only scientific) are still weak and little attested, identity conflicts and reactive identities are emerging: that is, identities that are such only in opposition to someone else (Allievi, 2005). We find them today in Europe among the very many people who on the political and intellectual plane have been rediscovering their Christian roots only since the Muslims have been present, and in opposition to them, perhaps through controversies over religious symbols, as is the case in Italy of those over the crucifix and in France the hijab (and it is symptomatic of this identity reactivity that these positions are often found again, even more vociferous, among declared atheists - think of the Oriana Fallaci case, or Michel Houellebecq - than among believers). But we find them also among Muslims who have rediscovered their roots, manifesting them through customs they had interrupted (ranging from attending the mosque, to the insistence on the hijab itself, as far as self-segregation in ghetto-like communities) since they have been living in Europe. The same use of self-definition, on the part of Muslims (as well as of "anti-Muslim" autochthones), in terms of "community" is part of this process: as if they were really so, as if there were only one, as if all the members of the supposed community actually belonged to it, or adhered to it, or recognised themselves as part of it. To paraphrase a well-known book by Nathan Glazer (1997): We are all Culturalists now.

A good example of reactive identities is conflicts on Islamic symbols in Europe.

\section{Conflicts on Islamic symbols in the European public space}

74 The presence of Islam inside the European public space could not pass unobserved, either socially or culturally. It is too visible and "bulky" not to lead to debate and tension: a sign that it really is an event that touches sensitive chords, or that is perceived as such. To the point that, if we measure its effects, we at times have the impression of an open and thorough confrontation (on the subjects discussed in this section, see Maréchal, Allievi, Dassetto and Nielsen, 2003).

Islam is disputed in se, often through essentialist and simplistic interpretations of the kind of rapport between religion and politics that it proposes. Islam is then disputed in some of its aspects, in how they manifest themselves especially in Muslim countries: of these aspects, the most mediatised are certainly the condition of women and fundamentalism. Lastly, it leads to debate on the foundations of our societies, on the limits of their possibilities of "openness", on their boundaries, on the many interpretations of possible "tolerance thresholds". All this happens without there often being a direct confrontation/clash with Muslims: often it is a question of internal debates in the host society, about Muslims and Islam.

These debates on Islam are very wide-ranging, even if what sets them off and their temporal recurrences can be brought down to a limited number of issues. There are however some issues that also imply a social and cultural confrontation/clash which involves Muslim social actors directly (but not necessarily the Islam communities as a 
whole, as people too readily tend to say), and which have led to discussions, shows of hostility, forms of refusal or afterthoughts.

One has the sensation however that the debate that is emerging from these forms of tension has a common theme, and that this is what integration is, and how it can be attained: whether it be the Islamic schools or the hijab, mosques or associationism of radical inspiration, and in general anything that creates discussion and tension around Islamic subjects.

The question of the hijab is a typical case. Anyone who has had occasion to hold courses, seminars or conferences on Islam knows how sensitive, how intensely felt, this subject is: almost a point of reference for any discussion on the presence of Islam in the public space, and in general on the question of women in Islam and comparisons between the Western and the Islamic model, both too easily taken for granted.

79 From a controversy discussed in the public space, like that of the hijab, we pass to a controversy about the public space. Another issue frequently discussed is in fact that of mosques and cemeteries, not simply as such, but perceived as symbolic and central places for making Islam visible.

80 A point that seems even more crucial, implying as it does a perception of control of territory, and its symbolic imprinting. An aspect that even with all due caution could be studied not only with the tools of cultural sociology, and sociology tout court, but also with the categories proper to ethology and sociobiology. Control of and on territory, after all, is not only a cultural and symbolic fact: it is also (and remains, despite everything) a very concrete and material sign of dominion, of power.

81 Think in particular of the building of mosques, but also simply of the visibility of prayer halls in European cities: questions to which we can add the possibility of spreading the adhan, the summons to prayer, outside the mosques themselves, and the building of cemeteries or the granting of specific cemetery spaces. The latter a problem around which the level of hostility is sometimes surprising, considering the fact that granting burial to foreigners is a custom that goes back thousands of years, to be found in all cultures and religions, a fact of human pietas, not to mention religious traditions. And considering that, on the other hand, the fact that the immigrant no longer asks for his body to be sent back to the country of origin is, so to speak, a form of post mortem integration: the recognition at the very highest symbolic level that the ground in which he wishes to repose for his final sleep he considers his home.

The question of mosques is important for various reasons. On one hand, in fact, the presence of foreign communities would seem to presuppose as a quite obvious consequence that they would desire to have their own places of religious encounter according to the religion they belong to, as is the case with "internal" autochthonous minorities. But there have been at times surprising conflicts around this question: the sign of discomfort and refusal that is more profound than its specific target in this case. Conflicts that make one think that the question is not the fact in itself (hardly anyone who opposes them would say that they want to stop anyone praying: the reason evoked is always different), but something more profound, connected with symbolic appropriation of territory, which has also something to do with history and its reconstruction, but also with deep psychological and social dynamics, to understand which we would perhaps have to venture on to the insidious and slippery ground of cultural psychology. Without forgetting ethology, as I said before. 
83 culturalism, that is, from what we consider unacceptable and impossible to integrate in Islam, to the limits themselves of our capacity for and possibility of welcome.

\section{Islamophobia?}

Social processes are never simple. We may at times try to describe them in clear colours, but they actually always appear in chiaroscuro. The process - Islam settling in Europe and becoming visible - "is happening", that is true. But, even more, it is the object of discussion: and less for what it is, for its manifestations that are empirically observable on the ground, than for what it is in the public imagination, literally prejudicial (in the sense that the judgement is given before the observation), which surrounds it and in a certain sense anticipates it.

It is this that transforms the robes or the beard of a pious traditionalist Muslim into the uniform of an Islamic militant. And this is why the desire to erect mosques as a place of worship and assembly of the community is as it were semantically over-determined, overloaded with meanings that it does not possess, which are connected with fundamentalism and terrorism, or more often with the general fear of a cultural invasion, or the introduction of elements that are extraneous and potentially of the "enemy". This is also an example of the "cultural overload" (Pace, 1995) that often affects debates over Islam.

The media play a decisive role both as the expression of a culture - in this case Muslim cultures, in the plural - and as an instrument for reading and interpreting these same cultures, through news of Muslims spread by general and specialised media. What is more, they play a significant role, even if underestimated, as a means of building the Muslim communities and the keeping up of ties with the countries of origin. Lastly, the media are a sounding box for problems, and constructing criteria for interpretation of the same. Let us start from the question of the production of the social public imaginary ${ }^{11}$.

The public imagination is crucial. In a certain sense even more than the reality of ongoing social processes, it is from perception of these that much of the direction that they take and their "success" depends. This aspect is of fundamental important also for policies around Islam: which do not so much influence, as depend in great measure on the perception of the phenomenon.

88 I will not underline, even though it would be necessary, on the importance of history. I will just limit myself to say that in the case of Islam factors come into play that in the case of other Eastern religions and other cultures do not. I refer in particular to the long past of confrontation/clash with the European West and Christianity, through the Crusades, the long period of maritime conflict against the Saracens and barbarian pirates, but also more recently of colonisation and the complex drift of de-colonization. A story that is not yet over, which also includes the consequences of the Arab-Israel conflict, the Gulf war, and other moments of crisis. Not last, September 11 and its consequences, with the attack on Afghanistan and the War in Iraq today.

"L'Islam vis-à-vis de l'Occident, c'est le chat vis-à-vis du chien", wrote Braudel. And Delumeau, in his history of fear in the West, does not forget the role played by fear of Islam, traces of which are still to be found not only in history but in the lived reality of

Revue européenne des migrations internationales, vol. 21 - n²| 2005 
folklore ("Saracen" and "Moor" games, among others), in town-planning and landscapes (the "Saracen towers" that dot the Mediterranean coastlines), in proverbial lore (the Italian "mamma li turchi" - Help! The Turks!): a legacy that it would be ingenuous to think has no effect on the present day. And which weighs at least as much as the Orientalist tradition stigmatised for its defects, with some lack of generosity, by E. Saïd (1978). The media are unwitting offspring of this mentality, and they take it on board, and in doing so they re-produce it and so make it real, thus turning a legacy from yesterday into a problem of today.

In this complex mechanism of construction of the cultural public imaginary the media have a central role, which turns out to be more and more determining today, also because their role, following on the processes of globalisation, of which they are at the same time effect, cause and accelerator, is no longer just to inform, but actually to build our worlds of knowledge. And to build them not only through the traditional effects of vertical integration, inside single nation-states or single societies, or single public spheres, in the words of Habermas (1962), but also by connection and horizontal integration, inter-, trans- and super-national (the word integration, incidentally, must not fool us: it is anything but a-conflictual, in the same way as a-conflictual, at least from the sociological point of view, is not a word that we could use for society, whose equilibrium is by definition unstable, and in which conflict plays a physiological and determining role). These processes cannot be comprehended in a "mediacentric" view, so to speak (as happens in some studies on the relations between the media and Islam), and be limited to the social and cultural effects of the media themselves, but must be perceived as being capable of seeing their role inside wider social processes.

of many other factors, the presence of Islam, with the apertures and connections that it implies with other national public spheres and other cultural worlds, is a nonsecondary element of construction and "complexification" of this unusual form of public sphere, interrelated and necessarily, also beyond the will of its actors, open, and rich with consequences, often unexpected. In fact there is a process in progress, even if with counter-tendencies and withdrawal symptoms, that seems to be going in the direction of a substantial co-inclusion of Islam in the public sphere, as more in general in society, through the various paths of integration.

Lastly, the world of media visibility is also the world in which and through which Islam is also seen. And at the same time Muslims are indirectly the means by which Islam is being discovered: something that some seem to have a certain awareness of.

One of the ways of making Islam visible is what happens in exceptional cases, which we may interpret as hermeneutic accidents, a jamming in a certain sense of the interpretative codes, and of the representations of these. Think of the Rushdie case, the question of the headscarf or hijab in France and elsewhere, and other more local ones.

Here I just wish to note their basic logic, which helps to give a certain image of Islam (conflictual, for example), which also reverberates through the perception of the phenomenon as a whole, and on to the welcome reserved for the social actors who embody it.

95 Think also of the fate of concepts like jihad, that burst into the Western public imaginary as a decisive aspect, at least in the perception of it, of Islam and therefore of Muslims, and therefore also of Muslims in Europe; an interesting example of 
generalisation of a local(isable) concept at a global level, and along this path of its assimilation into a perception that is now trans-national.

One of its expressions is what a work that has had a certain amount of publicity has called "Islamophobia", an expression that has become much-used in all European countries where the Islamic question is important, among experts and especially among social actors, first of all obviously Muslims themselves (Runnymede Trust, 1997, known also as the Islamophobia Report).

The word Islamophobia has however an unpleasantly ring of victimisation to it. While it does refer to social facts that do definitely exist, and which it is important to monitor, its use is particularly seductive for Muslims, putting all the responsibility for its existence on to their host societies. Now, while it is no doubt true that inflammatory anti-Islamic messages have been spreading over Europe, which I look at below, Muslims and their leadership, their imams and their associations, bear a non-secondary part of the responsibility for their spreading: for the hypocrisy of some messages or the abstractness of others, for the violence of certain verbal attitudes (occasionally with too weak condemnations from other Muslims) or for the incomprehension of some basic categories and methodologies of common European thinking, for certain extremes of language or defensive lexical hair-splitting, as well as the explicit choice of violence of some people (from Mohamed Atta, who flew into the Twin Towers, to Muhammad Bouyeri, the murderer of Theo Van Gogh, to the suicide bombers operating on European soil - as in Madrid - or, beyond Europe, in the Islamic world, in Palestine as in Casablanca). Obviously they do not concern all the Muslims in Europe, and not necessarily the majority of them; but quite comprehensible they fall over all of them.

Islamophobia does not regard only, nor perhaps even mainly, the media, which are almost more an effect than a cause of it, even though they act as multipliers and driving force. It is present in politics and theologies, as well as in academia, at various levels and in the most diverse disciplines. It seems to me however that one of the successful elements of the term among the Islamic communities and politically correct spheres close to it is also to discharge the communicative responsibility of Islamophobia entirely on to non-Muslims. Now, if the mass media often have an "exaggerated" perception of Muslim positions, this is partly because the Islamic leaderships sometimes express them in that very manner.

Having said this, let us see how the Islamic enemy is constructed.

\section{The "method of discourse": a case of media/ intellectual cultural clash}

100 The debate in the public space on Islam is becoming more and more heated. But how are we to deal with it? To overturn Descartes, I think that "the method of discourse" can be summarised as follows. I will take some examples from the case of Italy, which I know best, but which can be found also in other European countries (on the case of France see for example Geisser, 2003).

101 Often, in attitudes concerning Islam, we shift (but I fear not unconsciously, even less "innocently") from a consideration - more or less profound - about Islam, "abstract" so to speak, or connected to the situation in some Muslim countries, to one on Muslims in Europe, and even to immigrants in general. I limit myself here to underline that to 
continually overlap the two levels, that of the image that we have of Islam (often based only on extreme cases) and that of "normal" immigration, is a dangerous game. The minimum that can be said is that it is not an incentive to integration. On one hand in fact it offers to autochthones a false vision of reality which only increases already preexisting phobias, which have a "foreign" as well as "historical" origin, but effects that are all "internal" (as we are taught by sociological constructionism, it does not matter if a thing is real or not: it is enough for it to be believed to be real, to produce real effects). On the other hand it favours responses in tune with the stimulus, which go from motivated rage to a defensive sense of being victimised, up to a generalised sensation of "extraneousness". With the result that this obsessive insistence on the Islamic "wolf" risks becoming a particularly dangerous and disturbing example of a self-fulfilling prophecy.

There is often an "expectation effect" around Islam, which brings about what the semiologist Ugo Volli has called "fattoidi" (factoids): strange creatures that resemble facts without actually being them. Possible, expected, even if not real, and more easily malleable and manipulated than reality itself; but which produce what the same observer has called semiotic pollution - a form of pollution that is less observed but not less dangerous: if not of pollution of places and bodies, then of consciousnesses. They have a "logic" that we have often seen at work: among the more significant examples, at the time of the Catholic Jubilee, the various G8 meetings, but also at elections and at Christmas, when possible risks of fundamentalist terror attacks are feared. The same happens cyclically, in many European countries, with the publication of reports from the respective intelligence services, on "expected" dangers from Islamic terrorism. Possible: who can say the contrary? But it is above all the alarm that is real, and it is this that gains the opening pages of newspapers and TV newscasts. And its effects, above all else cumulative, remain.

103 To quote from a specific but interesting case, the "cultural" debate on Islam developed relatively late in Italy, as opposed to other European countries. If only because the Islamic presence itself came later, and is still now numerically much lower than in most other countries. To compensate, it seems to be now recovering lost ground very rapidly, and even exporting its arguments and maitres-à-penser to countries in which the debate is of earlier date and more mature (I am thinking of the many translations of journalist Oriana Fallaci's books, 2001 and $2004{ }^{12}$, but also political scientist Giovanni Sartori, $2000^{13}$, and Cardinal Biffi's statements spreading beyond the Alps).

But how has this debate developed? How has it been formed? What is it based on? Let us see a few recent examples of the "cultural" debate on Islam in Italy.

First of all, the method. A culture, a civilisation, a religion, is defined a priori, starting from knowledge that is often completely patched up, scraps of information, secondhand readings: from these abstract definitions, "empirical" Muslims are "deduced". This is the "Sartori method". Or one can start from personal experiences here and there, in different times and places, and again the deduction is: Muslims here and now. This is the "Fallaci method". Or yet again one can give a theological definition of the "other", show his diversity and incompatibility with "our" principles, and then conclude that there is ontological incompatibility. This is the "Biffi method". All others are only variations on the theme.

106 Sartori, in synthesis, says: the Islamic model contemplates an overlap between religion and politics in a theocratic key (the implication is: not us), therefore Muslims think 
that, therefore they are dangerous for our way of life, therefore they cannot live among us.

Fallaci, in synthesis says: I have seen dangerous fanatics in Pakistan and Iran, Arafat thirty years ago blessed suicide bombers, today Muslims have carried out a terror attack on the Twin Towers (the subtext is: they are always like this), therefore Muslim immigrants are intrinsically dangerous, therefore we have to get rid of them.

Biffi, in synthesis says: we are Catholics, they are not (the subtext here is above all that we are Catholics: but also that they are completely other-than-us), they have theological structures and therefore of thought and therefore of behaviour that are different from ours, incompatible with ours, therefore we have the duty to protect ourselves, therefore the state must not let them in.

These are in synthesis the positions expressed. With success, because in an age in which things are much less clear than we would wish, peddlers of cheap certainties - a drug not less dangerous than many others - are very successful.

110 The major political consequence of this way of thinking can be seen in the odious campaign of the Lega Nord (North League, a xenophobic political party which is part of the coalition presently in power) against the Mosques and Muslims in general, with its corollary of visceral and primary oppositions. But the social and cultural consequences are much larger than this empirical example.

111 It would be easy to deconstruct one by one the arguments advanced to motivate the incompatibility of the systems of thought and therefore of life. On the level of principles: they are often described differently from how they are defined by those who live them - our definition does not correspond to the self-definition, which should lead us to have some doubts (are we sure we have understood properly?). On

the historical level: starting from the same principles, different political and social systems have been constructed in different times and places - which should make us cautious in front of too facile "deductions". On the social level: the situation to which we are referring today - that of Muslim immigrants in Europe - does not correspond to those of the Muslim countries to which we are referring to motivate the incompatibility. The category "Islam", used in this way, far from having any explicative value, risks to become completely useless if not misleading: more or less, as Saïd (1981) already denounced, like the category "negro-mentality" in order to understand black people.

112 There is more. There are some considerations to make also about how we define ourselves and our societies: are we sure that they correspond to our ideal types? For example, is the Christian identity of our land as evident as certain secular intellectuals and certain political leaders claim, even more than certain religious figures?

But the problem of interpretation can be reassumed in the therefore and the premises with which I reassumed the theorems cited. And in one basic idea.

114 The implicit presupposition in fact is: if a person belongs to a certain faith, this person cannot be different from what he or she is supposed to be, that is to how we define that particular faith. Pity that things do not work like that. Not even practising Catholics are simplistically "deducible" from an abstract definition of the basic principles of Catholicism. Imagine the non-practising ones, even if they are baptised...

115 The idea of shari'a, for example, with everything that it leads to in terms of relations between religion and politics, actually presupposes that the Muslims are the majority, 
and are working the levers of power. The problem is that where they are not the majority, and do not have power, the entire conceptualization of shari'a, and its consequences for the individual, changes, often radically. What theology do they follow then, in concrete terms? And again: are a Muslim in Morocco and one in Egypt equal (and neither of these will be the same as those who come from Senegal or Indonesia), the same Muslim once he has emigrated to Europe, the same individual twenty years later after his emigration, and yet again his son who was born here? Obviously not. Not even in their way of being Muslims. Probably not even in the things in which they believe. Certainly not in the way in which they believe.

\section{Conclusions}

116 There is in the background to the fear of Islam what seems to me to be a long-lasting trend in Western societies, increasingly manifested in recent decades: the generalisation of the social construction of fear, its systematic spreading, its omnipresence in the media, its political exploitation (Allievi, 2005). And as a consequence the spread of mentalities, even before policies, of obsession with security: in some cases also frankly paranoiac. The phenomenon is not new in itself. It seems to me that it is new in its modes of operation. And naturally in the choice of object (scapegoat?) of reference.

117 One of its effects is the steady disappearance from the public scene of other diversities: polarisation, at present, is on the Islamic one. Which is keeping up an incomparable level of visibility in respect to other cultural and religious phenomena, and also in respect to other problems that immigration does create, and which seem to have been pushed to the sides of the stage, including those of security, deviance, crime, even if extremely popular with the media. The only possible way out from this tendency seems to be a progressive de-islamization of the discussion on Muslims in Europe: a way out to the "exceptionalism" attributed by default to Islam. Something that does not seems to be on the agenda, at present.

We can easily foresee that the "Islamic diversity" will be with us for a long time in the European public debate. The path we traced at the beginning - the "other", the diverse, the foreigner, the immigrant, the Muslim - does not appear to be leading to anything new. At least for now.

\section{BIBLIOGRAPHY}

ABAZA M. (1993) Some Reflections on the Question of Islam and Social Sciences in the Contemporary Muslim World, Social Compass, 40, pp. 301-321.

ALLIEVI Stefano (1998) Les convertis à l'islam. Les nouveaux musulmans d'Europe, Paris, L'Harmattan, $383 \mathrm{p}$. 
ALLIEVI Stefano (2001) La tentazione della guerra. Dopo l'attacco al World Trade Center: a proposito di Occidente, islam ed altri frammenti di conflitto tra culture, Milano, Zelig, $190 \mathrm{p}$.

ALLIEVI Stefano (2002) Musulmani d'occidente. Tendenze dell'islam europeo, Roma, Carocci, 194 p.

ALLIEVI Stefano (2004a) Ragioni senza forza, forze senza ragione. Una risposta a Oriana Fallaci, Bologna, EMI, $159 \mathrm{p}$.

ALLIEVI Stefano (2004b) Inmigraciones y religiones en Europa. Identitades individuales y colectivas en trasformación, in Gemma Aubarell, Ricard Zapata eds., Inmigración y procesos de cambio. Europa y el Mediterráneo en el contexto global, Barcelona: Icaria-IEMed, pp. 319-350.

ALLIEVI Stefano (2005) Conflicts, cultures and religions. Islam in Europe as a sign and symbol of change in European societies, in Yearbook on Sociology of Islam (forthcoming).

ALLIEVI Stefano and DASSETTO Felice (1993) Il ritorno dell'islam. I musulmani in Italia, Roma, Edizioni Lavoro, 291 p.

AMIRAUX Valérie (2001), Acteurs de l'islam entre Allemagne et Turquie. Parcours militants et expériences religieuses, Paris, L'Harmattan, $329 \mathrm{p}$.

BECK Ulrich (1992) Risk Society. Towards a New Modernità, London, Sage, 260 p.

CARRE Olivier (1986) A propos de Weber et Islam, Archives de Sciences Sociales des Religions, 1, pp. 139-152.

CASANOVA José (1994) Public Religions in the Modern World, Chicago, University of Chicago Press. CHARNAY Jean Paul (1977) Sociologie religieuse de l'islam, Simbad, Paris.

DASSETTO Felice (1996) La construction de l'islam européen. Approche socio-anthropologique, Paris, L'Harmattan, $383 \mathrm{p}$.

DASSETTO Felice et BASTENIER Albert (1984) L'islam transplanté. Vie et organisation des minorités musulmanes de Belgique, Antwerp, Epo, 203 p.

DASSETTO Felice e BASTENIER Albert (1988) Europa: nuova frontiera dell'Islam, Roma, Edizioni Lavoro, $328 \mathrm{p}$.

FALLACI Oriana (2001) La rabbia e l'orgoglio, Milano, Rizzoli.

FALLACI Oriana (2004) La forza della ragione, Milano, Rizzoli.

FERRARI Silvio and BRADNEY Anthony eds. (2000), Islam and European Legal Systems, Aldershot, Ashgate, $203 \mathrm{p}$.

FRIGESSI CASTELNUOVO Delia e RISSO Michele (1982) A mezza parete. Emigrazione, nostalgia, malattia mentale, Torino, Einaudi, $212 \mathrm{p}$.

GARELLI Franco, GUIZZARDI Gustavo e PACE Enzo eds. (2003) Un singolare pluralismo. Il pluralismo morale e religioso degli italiani, Bologna, Il Mulino, pp.333.

GEISSER Vincent (2003) La nouvelle islamophobie, Paris, La Découverte, 122 p.

GERHOLM Tomas and LITHMAN Yngve Éds. (1988) The New Islamic Presence in Western Europe, London-New York, Mansell, 293 p.

GLAZER Nathan (1997) We are all multiculturalists now, Cambridge (Mass.), Harvard, University Press, $173 \mathrm{p}$. 
HABERMAS Jünger (1962) Strukturwandel der Oeffentlichkeit, Neuwied, Hermann Luchterhand Verlag, Italian Translation Storia e critica dell'opinione pubblica, Bari, Laterza, 372 p.

HADDAD Yvonne Éd. (2002) Muslimsin theWest.FromSojournerstoCitizens, Oxford, Oxford University Press, $318 \mathrm{p}$.

HUNTER Shireen Éd. (2002) Islam, Europe's Second Religion. The new social, cultural and political landscape, Westport, Praeger, 294 p.

HUNTINGTON Samuel (1996) The Clash of Civilizations and the Remaking of World Order, New York, Simon \& Schuster, $367 \mathrm{p}$.

JABES Edmond (1989) Un Etranger avec, sous les bras, un livre de petit format, Paris, Gallimard, $151 \mathrm{p}$. KEPEL Gilles (1987), Les banlieues de l'Islam. Naissance d'une religion en France, Paris, Seuil, 429 p. KHOSROKHAVAR Farhad (1997) L'islam des jeunes, Paris, Flammarion.

KURTZ Lester (1995) Gods in the Global Village. The World's Religions in Sociological Perspective, Pine Forge Press.

LANDMAN Nico (1992), Van mat tot minaret. De institutionalisering van de islam in Nederland, Amsterdam, VU Uitgeverij.

LEWIS Bernard and SCHNAPPER Dominique Éds. (1992), Musulmans en Europe, Toulouse, Actes Sud, $222 \mathrm{p}$.

LEWIS Philip (1994), Islamic Britain. Religion, Politics and Identity among British Muslims, London, I.B.Tauris

MAATOUK Frédéric (1992) Les contradictions de la sociologie arabe, Paris, L’Harmattan, 126 p.

MARECHAL Brigitte, ALLIEVI Stefano, DASSETTO Felice and NIELSEN Jørgen Éds. (2003) Muslims in the Enlarged Europe, Leiden, Brill, 602 p.

MARTINIELLO, Marco (1997) Sortir des ghettos culturels, Paris, Presses de Sciences Po, ??? p.

NIELSEN Jørgen (1992) Muslims in Western Europe, Edinburgh, Edinburgh University Press, 186 p.

NONNEMAN Gerd, NIBLOCK Tim and SZAJKOWSKI Boris Éds. (1996) Muslim Communities in the New Europe, Reading, Ithaca Press, 346 p.

PACE Enzo (1995) Islam e Occidente, Roma, Edizioni Lavoro, 129 p.

PACE Enzo (1999) Sociologia dell'islam. Fenomeni religiosi e logiche sociali, Roma, Carocci, 212 p.

SABAGH G. and GHAZALLA I. (1986) Arab sociology today: A view from within, Annual Review of Sociology, 12, pp. 373-399.

RUNNYMEDE TRUST (1997) Islamophobia. A challenge for us all, London, $69 \mathrm{p}$.

SAÏD Edward (1978) Orientalism, New York, Pantheon Books.

SAÏD Edward (1981) Covering Islam: How the Media and the Experts Determine How We See the Rest of the World, London, Routledge and Kegan Paul, 186 p.

SARTORI Giovanni (2000) Pluralismo, multiculturalismo e estranei, Milano, Rizzoli, 122 p.

SCHMIDT DI FRIEDBERG Ottavia (1994) Islam, solidarietà e lavoro, Torino, Edizioni della Fondazione Agnelli, 224 p.

SHADID Wasif and VAN KONINSVELD Sjoerd Éds. (1991), The Integration of Islam and Hinduism in Western Europe, Kampen, Kok Pharos. 
SHADID Wasif and VAN KONINSVELD Sjoerd (1995), Religious Freedom and the position of Islam in Western Europe, Kampen, Kok Pharos, 229 p.

SHADID Wasif and VAN KONINSVELD Sjoerd eds. (2002), Religious Freedom and the Neutrality of the State: the Position of Islam in the European Union, Leuven, Peeters

SHARI'ATI Ali (1979) On the Sociology of Islam, Berkeley, Mizan Press, 132 p.

SIMMEL Georg (1908) Soziologie, Berlin, Duncker \& Humblot, Italian Translation Sociologia, Milano, Edizioni di Comunità, 1989, 665 p.

SOCIAL COMPASS (1999) Les Conversions à l'Islam en Europe, London, Sage Publications, pp. 243-362.

TURNER Bryan (1974) Weber and Islam, London, Routledge \& Kegan Paul.

VERTOVEC Steve and PEACH Ceri eds. (1997) Islam in Europe. The politics of religion and community, London-New York, Macmillan-St.Martin's Press.

VERTOVEC Steve and ROGERS A. eds. (1998) Muslim European Youth - Reproducing Ethnicity, Religion, Culture, Aldershot, Ashgate, $215 \mathrm{p}$.

VAN NIEUWKERK Karin (forthcoming) Gender and conversion to Islam in the West, Austin, Texas University Press.

WAARDENBURG Jaques et alii (1994) I musulmani nella società europea, Torino, Edizioni della Fondazione Agnelli, 177 p.

\section{NOTES}

1. As well as the century that saw the rise and fall of the most devastating forms of totalitarianism (that is, the negation at the roots of any diversity) and some of the greatest massacres that history has ever known. I do not here intend to enter into the relations between the two things: search for the otherness and negation of the other (tempting and risky at the same time). I will just limit myself to touch upon the first aspect.

2. Same meaning presupposed in expressions such as the French main-d'oeuvre or the Italian manodopera.

3. Nostalgia as a peculiar form of mental disease, on which Frigessi Castelnuovo and Risso (1982).

4. A detailed periodisation, which compares migratory cycles and "Muslim cycles", can be found in Dassetto (1996), and more synthetically in Allievi and Dassetto (1993).

5. On the two aspects, theoretical and empirical, respectively, see the essays by Guizzardi and Allievi in Garelli, Guizzardi and Pace, 2003. For a more general discussion of the difficulty of using the category of religious pluralism in sociological theory, see Allievi, $2004 \mathrm{~b}$.

6. Some examples, normally the outcome of a seminar, are Gerholm and Lithman (1988), Shadid and van Koningsveld (1991 and 2002, to quote just the oldest and the more recent), Lewis and Schnapper (1992), Waardenburg and others (1994), Nonneman, Niblock and Szajkowski (1996), Vertovec and Peach (1997), Ferrari and Bradney (2000), Haddad (2002), Hunter (2002).

7. The local studies are too numerous to quote them. They constitute an important literature to refer to, when in search of empirical works: too often, unfortunately, with lack of theoretical profundity. Some examples of texts on national situations, which from different point of views have opened the debate on the Islamic presence in their respective countries, have been,among others, Dassetto and Bastenier (1984) for Belgium, Kepel (1987) for France, Landmann (1992) for Holland, Allievi and Dassetto (1993) for Italy, and Lewis (1994) for Britain.

8. To quote only two examples, Schmidt of Friedberg (1994) and Amiraux (2001). 
9. Among others Dassetto and Bastenier (1988), Nielsen (1992), Shadid and van Koningsveld (1995), Dassetto (1996), Allievi (2002).

10. On minority Islam, on its "Meccan" and "ummic" character, see Allievi 2002 and 2005).

11. For further discussion see the chapter on the media that I wrote for Maréchal et alii (2003).

12. On which I have extensively commented and to which I have tried to respond in Allievi 2001 and 2004a.

13. To which I have responded all the same in Allievi 2001.

\section{ABSTRACTS}

How the Immigrant has Become Muslim. Public Debates on Islam in Europe.

Sociology has often taken into account figures such as the "other" and the concept of otherness. In classical sociology the other was more frequently the internal minority, then the immigrant. More recently the ideal-type of the "other" has often become the Muslim. Many reasons can explain this shift. Some of them are obviously linked to recent changes: the increasing number of immigrants of Muslim origin living in European countries, with the socio-cultural problems linked to this presence, on one hand, and the emerging role of Islam as a public actor on the global scene, included through fundamentalism and terrorism, on the other.

Other reasons are less conjectural, and are related to long term evolutions in the European societies. One of these is the increasing use of religious categories in the interpretation of social, cultural and political problems, particularly in the mediated arena: Islam and Muslims can be considered the extreme case of this kind of debates, in which the pertinence of the religious categories is hardly discussed, and is considered "legitimate" or self-evident, often without discussion. From this point of view, the public debates on Islam increasingly move from reductionism to essentialism. The paradox of this situation is that, while the processes of integration of Muslims in European societies becomes more and more empirically an evidence, the perception of Muslims often becomes more and more full of conflicts. This fact is particularly visible in the controversies about Islamic symbols in the public space, and in intellectual and mediated debates about books (such as those of Oriana Fallaci).

Parmi les figures de l'altérité que la sociologie a conceptualisées, on a pu voir le passage de la minorité interne à l'étranger, puis à l'immigré, qui a été longtemps l'idéal-type de "l'Autre ». Ces dernières années il semble remplacé par le musulman. De nombreuses raisons expliquent ce passage. Les unes sont liées à la conjoncture, qu'il s'agisse des transformations de l'immigration en Europe ou de l'émergence de l'Islam comme acteur global. D'autres renvoient à des évolutions à long terme comme l'utilisation croissante des catégories interprétatives fondées sur la religion dans le débat public européen, l'Islam représentant le cas extrême de cette utilisation. Cette position de l'Islam semble fondée d'une part sur la méconnaissance de ses spécificités religieuses, et de l'autre sur l'utilisation de la religion comme une explication évidente, même lorsque des raisons non religieuses sont à l'origine de certains phénomènes. La recherche, tout comme le débat politique, religieux, et surtout médiatique sur l'Islam semble donc osciller entre l'essentialisme et le réductionnisme.

Le paradoxe de cette situation, est qu'alors que le processus d'intégration des musulmans dans la société européenne est en cours, la perception des musulmans comme de l'Islam devient de plus en plus conflictuelle. En témoignent les oppositions à la présence des symboles islamiques en 
Europe (hijab, mosquées, etc.) et les débats intellectuels et médiatiques autour d'ouvrages comme celui d'Oriana Fallaci.

Como el inmigrante se volvió un musulmán. Debates públicos sobre el Islam en Europa.

Entre las figuras de la alteridad conceptualizadas por la sociología, se puede observar el pasaje de la minoría interna al extranjero y luego al inmigrante, que fue durante largos años el ideal-tipo del «Otro». Estos últimos años, parece que lo reemplazó el musulmán. Muchas son las razones que explican este cambio. Unas son coyunturales, como las transformaciones de la inmigración en Europa o la emergencia del Islam como actor global. Otras resultan de de evoluciones a largo plazo como el uso creciente en el debate público europeo de categorías interpretativas basadas en la religión, el Islam siendo el caso extremo de esta utilización. Esta tendencia puede resultar del conocimiento escaso de las especifidades religiosas del Islam, y también del uso de la religión como una explicación evidente, aunque hechos sin relación con ella estén a la raíz de ciertos fenómenos. La investigación científica, como el debate político, religioso y sobre todo mediático sobre el Islam oscila entre esencialismo y reduccionismo. Esta situación es paradójica: mientras se desarrolla el proceso de integración de los musulmanes en la sociedad europea, la percepción del Islam se vuelve cada día mas conflictiva como lo demuestran la oposición a la presencia de símbolos islámicos en el espacio público (hijab, mezquitas) y los debates intelectuales y mediáticos alrededor de libros como el de Oriana Fallacci.

INDEX

Mots-clés: islam, musulmans, représentations

Geographical index: Europe

\section{AUTHOR}

\section{STEFANO ALLIEVI}

Professor of Sociology at the University of Padua, Faculties of Sciences of Communication and of Political Sciences. Stefano.allievi@pop.unipd.it 